\title{
Seasonal influence of drifting seaweeds on the structure of fish assemblages on the eastern equatorial Brazilian coast
}

\author{
Natália Carla Fernandes de Medeiros Dantas ${ }^{1 *}$, Carlos Antônio Beserra da Silva Júnior ${ }^{2}$, Caroline \\ Vieira Feitosa ${ }^{3,4}$, Pedro Bastos de Macedo Carneiro ${ }^{3}$
}

\author{
${ }^{1}$ Programa de Pós-Graduação em Engenharia de Pesca, Universidade Federal do Ceará (UFC). \\ (Avenida Mister Hull, 2977, Campus do Pici, CEP: 60356-001, Fortaleza, Ceará, Brazil). \\ 2 Programa de Pós-Graduação em Recursos Pesqueiros e Aquicultura, Universidade Federal Rural de Pernambuco (UFRPE). \\ (Rua Dom Manoel de Medeiros, s/n, Bairro de Dois Irmãos, CEP: 52171-030, Recife, Pernambuco, Brazil). \\ ${ }^{3}$ Universidade Federal do Ceará (UFC), Instituto de Ciências do Mar \\ (Avenida Abolição, 3207, Bairro Meireles, CEP: 60165-081, Fortaleza, Ceará, Brazil). \\ ${ }^{4}$ Grupo de Ictiologia Marinha Tropical (IMAT). \\ (Av. Prof. Moraes Rego, 1235, Cidade Universitária, CEP: 50670-901, Recife, Pernambuco, Brazil).
}

*Corresponding author: nataliacarladantas@hotmail.com

\section{Abstract}

The present study compared fish assemblages in two adjacent areas, one with drifting algae (A) and another without it (WA), in order to assess seasonal changes in diversity and composition. Both areas were located in São Cristóvão beach, Rio Grande do Norte state, on the semi-arid North-Northeastern coast of Brazil. A total of 4988 individuals were caught, the most species-rich families being Scianidae, Ariidae, Engraulidae and Carangidae. Species richness and abundance were slightly higher in site A, but diversity and evenness were higher in site WA. However, with the exception of evenness, such differences were not significant at any time during the study. Species composition was also similar between the two sites over the year. Nevertheless, in spite of the similarities, seasonal changes of environmental conditions, particularly rainfall, seemed to influence fish assemblages differently in the two areas. This may have led to changes in assemblage structure, causing the differentiation of the communities in the dry season. The present study presents evidence that fish assemblages in habitats with and without drifting seaweeds are not static and may become more similar or different, depending on the environmental conditions, suggesting that there is a complex relationship between primary productivity, trophic level and the structure of fish assemblages.

Descriptors: Fish communities, Macroalgae, Rainfall season, Dry season, Primary productivity, Bottom trawls.

\section{REsumo}

O presente estudo comparou assembleias de peixes em duas áreas adjacentes, uma com algas à deriva (A) e outra ausente de algas (WA), a fim de avaliar as mudanças sazonais na sua diversidade e composição. Ambas as áreas estão localizadas na praia de São Cristóvão, Rio Grande do Norte, na região semiárida, costa Norte-Nordeste do Brasil. Um total de 4988 indivíduos foram capturados, sendo as famílias mais ricas em espécies Ariidae, Engraulidae e Carangidae. A riqueza de espécies e abundância foi ligeiramente superior no local A, e a diversidade e equitabilidade no local WA. No entanto, com exceção da equitabilidade, tais diferenças não foram significativas ao longo do estudo. A composição de espécies também foi semelhante entre os dois locais ao longo do ano. No entanto, apesar das semelhanças, as mudanças sazonais de condições ambientais, particularmente precipitação, influenciaram as assembleias de peixes de forma diferente nas duas áreas. Isto causou mudanças na estrutura das assembleias, ocasionando uma diferenciação das comunidades na estação seca. O presente estudo traz evidências de que as assembleias de peixes em habitats com e sem algas à deriva não são estáticos e podem se tornar mais semelhantes ou diferentes, dependendo das condições ambientais, sugerindo a existência de uma complexa relação entre produtividade primária, nível trófico e estrutura da assembleia.

Descritores: Comunidade de peixes, Macroalgas, Estação chuvosa, Estação seca, Produtividade primária, Redes de arrasto de fundo. 


\section{INTRODUCTION}

Drifting seaweeds are a characteristic feature of many marine ecosystems (ÓLAFSSON, 1988). They often accumulate in sheltered coastal regions, in areas with large nutrient concentrations, intense light and low exposure to waves (NORTON; MATHIESON, 1983). Being passively transported by the action of waves and currents, hydrodynamics is one of the contributing factors to the local establishment of these algae masses (BIBER, 2007a).

The transport of drift seaweeds is an important dispersion mechanism for both flora and fauna (BIBER, 2007b), particularly between sandy-bottom habitats and neighboring ecosystems (HOLMQUIST, 1994). This transport influences the colonization and dispersion of larvae, juveniles and adults of many species of invertebrates and fishes (BIBER, 2007a). Moreover, in areas where drift algae accumulates, there is usually a high abundance of fishes and invertebrates (KULCZICK et al., 1981; VIRNSTEIN; HOWARD, 1987), which use these seaweeds as a refuge during migrations between open sea and coastal habitats (SMITH; HERRNKIND, 1992; HOLMQUIST, 1994; WANG et al., 2003). On tropical beaches, such accumulations provide an important resource for juvenile fishes, increasing their chances of survival by providing shelter and food (ANDRADES et al., 2004).

Despite the importance of drift algae to fish assemblages, their passive mode of transport and accumulation suggests that this relationship is mediated by environmental conditions (KINGSFORD, 1990; KINGSFORD, 1992; BIBER, 2007a). Seasonal variations in tides and wind speed, for example, do affect the drifting dynamics, influencing algal accumulations and consequently their associated fauna (KINGSFORD, 1995; RIEGL et al., 2005; BIBER, 2007b). On the other hand, fish assemblages' structure and composition may also vary seasonally due to causes unrelated to seaweeds, such as migrations, recruitment and mortality (GALVÁN-PIÑA et al., 2003; BARREIROS et al., 2004; RIBEIRO et al., 2006; MASUDA, 2008; FOWLER; BOOTH, 2013).

In spite of these possible seasonal variations, the influence of drifting algae on fish assemblages was mainly assessed on short time scales, and most studies were limited by their investigating only communities already inside seaweed masses (STONER; LIVINGSTON, 1980; KULCZYCKI et al., 1981; KINGSFORD, 1995; ANDRADES et al., 2014). The scarce literature available undertaking comparisons (e.g. EVERETT, 1994) with areas without drifting seaweeds may conceal the effects of algal masses among the effects of other possible sources of variation of fish communities.

The present study aims to compare, within the same geographical area, seasonal variations of fish assemblages in areas with or without drifting algae. Our main objective is to better understand the isolated effect of drift algae on fish assemblages, and to test the following hypotheses: (1) the diversity and abundance of fishes are higher in the presence of drift seaweeds and (2) the presence of drift algae affects seasonal variations in fish assemblages.

\section{MATERIAL AND METHODS}

\section{STUDY SITE}

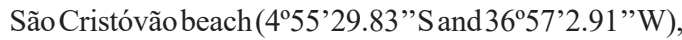
is located on the eastern equatorial coast of Brazil, on the northern coastline of Rio Grande do Norte state (Figure 1). Shaped in the form of a bay, this beach has a dissipative surf zone and a predominantly sandy-muddy soft-bottom, with occasional occurrences of seagrass meadows. The region has a hot semi-arid climate (BSh in the Köppen classification), with rains mostly limited to February-May and mean annual rainfall below $750 \mathrm{~mm}$ (IDEMA, 2008).

\section{SAMPLING STRATEGY}

Twelve campaigns were undertaken to analyze the relationship between fish and drift seaweeds, one per month from February 2010 to January 2011. On each campaign, fish assemblage structure and composition were assessed by two bottom trawls. These were conducted at two sites off São Cristóvão beach, one with drifting macroalgae (A) and another devoid of vegetation (WA). These sites were both about $6 \mathrm{~m}$ deep, were situated approximately $800 \mathrm{~m}$ from the shore and $400 \mathrm{~m}$ apart. Both had the characteristic sandy-muddy substrate and neither contained seagrass beds.

Bottom trawls were run parallel to the coastline, following the direction of the current, each lasting 10 minutes, during low spring tide. The fishing nets were $15 \mathrm{~m}$ long, $8.60 \mathrm{~m}$ wide and had a mesh size of $4 \mathrm{~cm}$. These nets were pulled by a shrimp boat equipped with a 6-cylinder $46 \mathrm{HP}$ engine, navigating at 2.5 knots (aprox. $3.7 \mathrm{~km} / \mathrm{h}$ ). Fishes were identified and deposited at the biological collection of Laboratório de Biologia de Peixes Marinhos e Dinâmica Populacional of the Universidade Federal Rural do Semiárido (UFERSA) under access numbers $1-50$. 


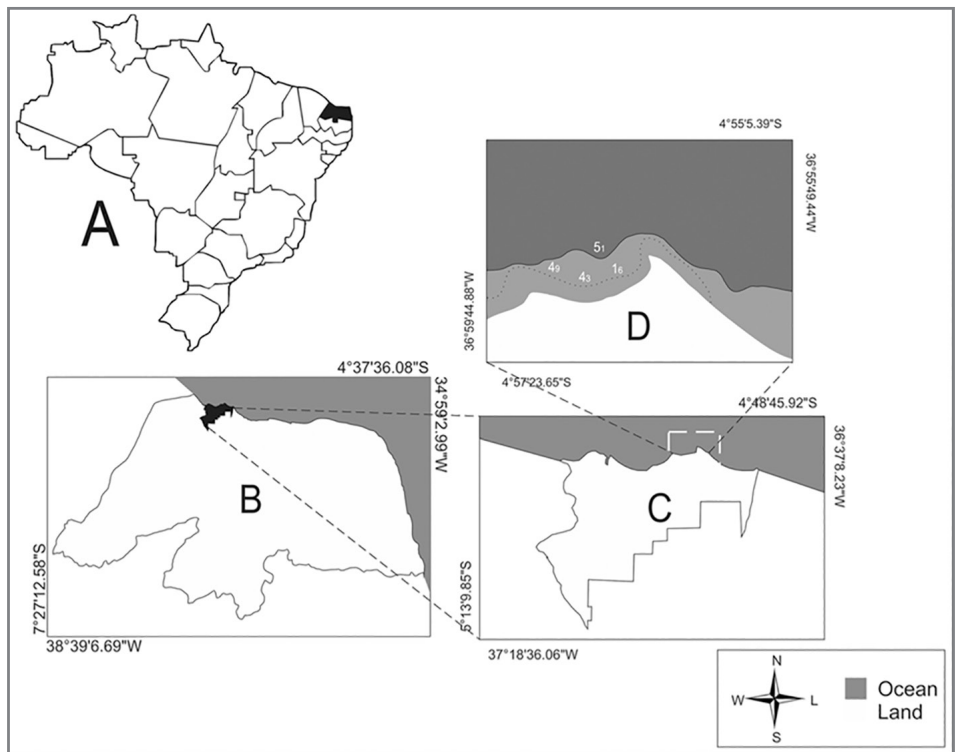

Figure 1. Location of the study area at São Cristóvão beach, eastern equatorial coast of Brazil.

\section{DATA ANALYSIS}

Frequency of occurence $(C)$ was calculated following DAJOZ (1983), by the formula: $C i=(p i \times 100) / P$, where $C i$ is the frequency of occurrence of species $i$; pi is the number of samples with species $i$; and $P$ is the total number of samples. According to their occurrence, fish species were classified as: constant $(\mathrm{CON})$ when present in more than $50 \%$ of samples, accessory (ACS) when present in $25 \%-50 \%$ of samples, or accidental (ACD) when present in less than $25 \%$ of samples.

Fish assemblages in both A and WA were described by the following ecological indexes: richness, abundance, Pielou's eveness (J) and Shannon's diversity (H). Depending on the nature of the data, Student's $t$ test or Mann-Whitney's U test was used to check if there were differences between the indices of the two sites (A and WA). The normality of the data was verified by Lilliefors' test and the equality of variances by Levene's test. In the cases where the $U$ test was applied, we assumed that the data had equal distributions and the analysis was interpreted as testing for differences between the medians.

Temporal variations in indexes of $\mathrm{A}$ and WA were compared by means of Pearson's linear correlation. Additionally, analyses of the correlations between the indexes and mean monthly wind speed $\left(\mathrm{m} . \mathrm{s}^{-1}\right)$ and rainfall $(\mathrm{mm})$, were used to explain possible influences of climatic variables. These data were obtained from the meteorological station of the Instituto Nacional de Meteorologia (INMET) located in the municipality of Macau. For the correlation with climatic variables, data were log-transformed $(\log +1)$.
Bray-Curtis dissimilarity was used to assess differences in species composition between assemblages of A and WA. This non-metric distance measures the differences in species composition between communities, ranging from 0 when communities are equal to 1 when they are completely different (BRAY; CURTIS, 1957). Temporal variations of this dissimilarity were analyzed via correlation analysis. To test whether any observed difference was significant, an Analysis of Similarity (ANOSIM) was employed. In addition, a graphical representation of data was constructed by non-metrical Multidimensional Scaling (nMDS). Finally, Similarity Percentage (SIMPER) was used to determine which species were those mainly responsible for the differences between assemblages.

\section{RESULTS}

The bottom trawls resulted in a total catch of 4988 individuals, belonging to 51 species, 42 genera and 24 families (Table 1). Richness was higher in site A, but most species were present in both locations (Figure 2A). The most species-rich families were Scianidae, Ariidae, Engraulidae and Carangidae.

Based on the frequency of occurrence, most species from both locations were classified as accidental (Figure 2B), indicating a high temporal variability of fish assemblages. On the other hand, species with the highest abundances at both sites (i.e. Cathorops spixii, Pomadasys corvinaeformis and Pellona harroweri in A; Stellifer rastrifer, Pomadasys corvinaeformis and Stellifer stellifer 
Table 1. List of fish taxa, with their respective densities and occurrence classes, at two sites on São Cristóvão beach, eastern equatorial coast of Brazil. One site with drift algae (A) and another with bare substrate (WA). Density was calculated as abundance divided by sampled area (area covered by the fishing net), with values standardized to $100 \mathrm{~m}^{2}$. Regarding occurrence, species were classified as constant (CON), accessory (ACS) or accidental (ACD).

\begin{tabular}{|c|c|c|c|c|}
\hline \multirow[t]{2}{*}{ Family/Species } & \multicolumn{2}{|c|}{ Density } & \multicolumn{2}{|c|}{ Occurrence } \\
\hline & $\mathrm{A}$ & WA & $\mathrm{A}$ & WA \\
\hline \multicolumn{5}{|l|}{ Pristigasteridae } \\
\hline Chirocentrodon bleekerianus (Poey. 1867) & 3.53 & 2.47 & ACS & ACS \\
\hline Pellona harroweri (Fowler. 1917) & 4.82 & 3.68 & $\mathrm{CON}$ & $\mathrm{CON}$ \\
\hline \multicolumn{5}{|l|}{ Engraulidae } \\
\hline Anchoa filifera (Fowler 1915) & 0.02 & 0.05 & $\mathrm{ACD}$ & $\mathrm{ACD}$ \\
\hline Anchoa spinifer (Valenciennes. 1848) & 0.81 & 0.39 & $\mathrm{CON}$ & $\mathrm{CON}$ \\
\hline Anchoa tricolor (Agassiz. 1829) & 0.02 & 0.27 & $\mathrm{ACD}$ & $\mathrm{ACD}$ \\
\hline Cetengraulis edentulus (Cuvier. 1829) & 0.12 & 0.60 & $\mathrm{ACD}$ & ACS \\
\hline \multicolumn{5}{|l|}{ Clupeidae } \\
\hline Opisthonema oglinum (Lesueur. 1818) & - & 0.06 & - & $\mathrm{ACD}$ \\
\hline \multicolumn{5}{|l|}{ Ariidae } \\
\hline Bagre bagre (Linnaeus. 1766) & 0.03 & 0.20 & $\mathrm{ACD}$ & $\mathrm{ACD}$ \\
\hline Bagre marinus (Mitchill. 1815) & 0.06 & 0.11 & $\mathrm{ACD}$ & $\mathrm{ACD}$ \\
\hline Cathorops spixii (Agassiz. 1829) & 13.08 & 2.43 & $\mathrm{CON}$ & $\mathrm{CON}$ \\
\hline Genidens barbus (Lacépède. 1803) & 0.24 & 0.09 & $\mathrm{ACD}$ & $\mathrm{ACD}$ \\
\hline Notarius grandicassis (Valenciennes. 1840) & 0.06 & - & $\mathrm{ACD}$ & - \\
\hline \multicolumn{5}{|l|}{ Synodontidae } \\
\hline Synodus intermedius (Spix; Agassiz. 1829) & 0.03 & - & $\mathrm{ACD}$ & - \\
\hline \multicolumn{5}{|l|}{ Batrachoididae } \\
\hline Thalassophryne nattereri Steindachner. 1876 & - & 0.02 & - & $\mathrm{ACD}$ \\
\hline \multicolumn{5}{|l|}{ Dactylopteridae } \\
\hline Dactylopterus volitans (Linnaeus. 1758) & 0.09 & 0.02 & ACS & $\mathrm{ACD}$ \\
\hline \multicolumn{5}{|l|}{ Triglidae } \\
\hline Prionotus punctatus (Bloch. 1793) & 0.08 & 0.03 & ACS & $\mathrm{ACD}$ \\
\hline \multicolumn{5}{|l|}{ Carangidae } \\
\hline Chloroscombrus chrysurus (Linnaeus. 1766) & 0.18 & 0.05 & ACS & $\mathrm{ACD}$ \\
\hline Selene setapinnis (Mitchill. 1815) & 0.78 & 0.42 & $\mathrm{CON}$ & $\mathrm{CON}$ \\
\hline Selene vomer (Linnaeus. 1758) & 0.18 & 0.39 & ACS & ACS \\
\hline Uraspis secunda (Poey. 1860) & 0.03 & - & $\mathrm{ACD}$ & - \\
\hline \multicolumn{5}{|l|}{ Lutjanidae } \\
\hline Lutjanus synagris (Linnaeus. 1758) & 0.03 & 0.02 & $\mathrm{ACD}$ & $\mathrm{ACD}$ \\
\hline \multicolumn{5}{|l|}{ Gerreidae } \\
\hline Diapterus rhombeus (Cuvier. 1829) & 0.03 & 0.03 & $\mathrm{ACD}$ & $\mathrm{ACD}$ \\
\hline Eucinostomus melanopterus (Bleeker. 1863) & 0.03 & - & $\mathrm{ACD}$ & - \\
\hline \multicolumn{5}{|l|}{ Haemulidae } \\
\hline Conodon nobilis (Linnaeus. 1758) & 0.96 & 0.39 & $\mathrm{CON}$ & ACS \\
\hline Genyatremus luteus (Bloch. 1790) & 0.09 & - & $\mathrm{ACD}$ & - \\
\hline Haemulon aurolineatum Cuvier. 1830 & 0.02 & - & $\mathrm{ACD}$ & - \\
\hline Pomadasys corvinaeformis (Steindachner. 1868) & 6.69 & 4.40 & $\mathrm{CON}$ & $\mathrm{CON}$ \\
\hline \multicolumn{5}{|l|}{ Sparidae } \\
\hline Taxon & \multicolumn{2}{|c|}{ Density } & \multicolumn{2}{|c|}{ Occurrence } \\
\hline Archosargus probatocephalus (Walbaum. 1792) & 0.03 & - & $\mathrm{ACD}$ & - \\
\hline Archosargus rhomboidalis (Linnaeus. 1758) & 0.03 & - & $\mathrm{ACD}$ & - \\
\hline \multicolumn{5}{|l|}{ Polynemidae } \\
\hline Polydactylus virginicus (Linnaeus. 1758) & 0.32 & 0.33 & $\mathrm{CON}$ & ACS \\
\hline \multicolumn{5}{|l|}{ Sciaenidae } \\
\hline Bairdiella ronchus (Cuvier. 1830) & 0.30 & 0.02 & ACS & $\mathrm{ACD}$ \\
\hline
\end{tabular}


Continued Table 1.

\begin{tabular}{|c|c|c|c|c|}
\hline Isopisthus parvipinnis (Cuvier. 1830) & 0.26 & 0.24 & ACS & ACS \\
\hline Larimus breviceps Cuvier. 1830 & 4.36 & 2.35 & $\mathrm{CON}$ & $\mathrm{CON}$ \\
\hline Menticirrhus americanus (Linnaeus. 1758) & 1.51 & 1.10 & $\mathrm{CON}$ & $\mathrm{CON}$ \\
\hline Nebris microps Cuvier. 1830 & 0.03 & 0.03 & $\mathrm{ACD}$ & $\mathrm{ACD}$ \\
\hline Paralonchurus brasiliensis (Steindachner. 1875) & 0.02 & - & $\mathrm{ACD}$ & - \\
\hline Stellifer brasiliensis (Schultz.. 1945) & 0.06 & 0.08 & $\mathrm{ACD}$ & $\mathrm{ACD}$ \\
\hline Stellifer rastrifer (Jordan. 1889) & 2.91 & 4.91 & $\mathrm{CON}$ & $\mathrm{CON}$ \\
\hline Stellifer stellifer (Jordan; Snyder. 1902) & 2.56 & 4,10 & $\mathrm{CON}$ & $\mathrm{CON}$ \\
\hline \multicolumn{5}{|l|}{ Mullidae } \\
\hline Pseudupneus maculatus (Bloch. 1793) & 0.02 & - & $\mathrm{ACD}$ & - \\
\hline \multicolumn{5}{|l|}{ Ephipiidae } \\
\hline Chaetodipterus faber (Broussonet. 1782) & 0.18 & 0.02 & ACS & $\mathrm{ACD}$ \\
\hline \multicolumn{5}{|l|}{ Acanthuridae } \\
\hline Acanthurus chirurgus (Bloch. 1787) & 0.02 & - & $\mathrm{ACD}$ & - \\
\hline \multicolumn{5}{|l|}{ Sphyraenidae } \\
\hline Sphyraena guachancho Cuvier. 1829 & 0.02 & 0.02 & $\mathrm{ACD}$ & $\mathrm{ACD}$ \\
\hline \multicolumn{5}{|l|}{ Trichiuridae } \\
\hline Trichiurus lepturus Linnaeus. 1758 & 0.20 & 0.24 & ACS & ACS \\
\hline \multicolumn{5}{|l|}{ Paralichthydae } \\
\hline Citharichthys macrops Dresel. 1889 & 0.14 & 0.03 & ACS & $\mathrm{ACD}$ \\
\hline Citharichthys spilopterus Günther. 1862 & 0.03 & 0.03 & $\mathrm{ACD}$ & $\mathrm{ACD}$ \\
\hline \multicolumn{5}{|l|}{ Achiridae } \\
\hline Trinectes paulistanus (Miranda Ribeiro. 1915) & - & 0.02 & - & $\mathrm{ACD}$ \\
\hline \multicolumn{5}{|l|}{ Cynoglossidae } \\
\hline Symphurus plagusia (Bloch; Schneider. 1801) & 0.03 & - & $\mathrm{ACD}$ & - \\
\hline Symphurus tesselatus (Linnaeus. 1766) & 0.18 & 0.02 & $\mathrm{CON}$ & $\mathrm{ACD}$ \\
\hline \multicolumn{5}{|l|}{ Tetraodontidae } \\
\hline Sphoeroides greeleyi Gilbert. 1900 & 0.02 & 0.03 & $\mathrm{ACD}$ & $\mathrm{ACD}$ \\
\hline \multicolumn{5}{|l|}{ Diodontidae } \\
\hline Chilomycterus spinosus spinosus (Linnaeus. 1758) & 0.03 & 0.15 & ACS & ACS \\
\hline
\end{tabular}

in WA) were also constant, suggesting the presence of at least some characteristic species, instead of only transient schooling aggregates. The species Selene setapinnis, Anchoa spinifer, Conodon nobilis, Polydactylus virginicus and Menticirrhus americanus, despite being constant in both sites, appeared at low abundances throughout the study. Only one species, M. americanus, was found in all 12 campaigns in both locations.

Table 2 summarizes mean annual values of all four ecological indexes. With the exception of Pielou's eveness index $(\mathrm{U}=38, p=0.049)$ these descriptors did not differ significantly between sites. Furthermore, in the case of evenness, the $U$ test shows the significant difference in median values better (better than would mean values, as would be expected in parametric tests), since data distribution seems to be equal in both locations. Hence median annual evenness changed from 0.60 in A to 0.75 in WA.

Regarding temporal variations of assemblages (Figure 3), a significant correlation was found only between the richness of the two locations $(\mathrm{r}=0.64, p=0.03)$. There seemed to be no correlation of the other indexes between sites, suggesting that the assemblages followed different patterns of change over the months. Furthermore, within site A there was a relationship between rainfall and both Shannon's diversity $(\mathrm{r}=0.69, p=0.01)$ and Pielou's eveness indices $(\mathrm{r}=0.74, p=0.006)$. Whereas in site WA the correlation was only between rainfall and richness $(r=0.59, p=0.04)$, wind speed did not seem to significantly affect any of the assemblages. On the other hand, both sites showed a significant correlation between species richness and abundance of individuals (A: $\mathrm{r}=0.77$, $p=0.003$; WA: $\mathrm{r}=0.58, p=0.047$ ).

Both assemblages were very similar throughout the study. The nMDS (Figure 4) resulted in a weak representation of data (stress $=0.20)$ that did not show a clear separation of sites, and the overall ANOSIM was not significant $(\mathrm{r}=0.005, p=0.38)$. However, the degree of similarity changed over the months, and the assemblages were more closely similar in the first half of the year. This 


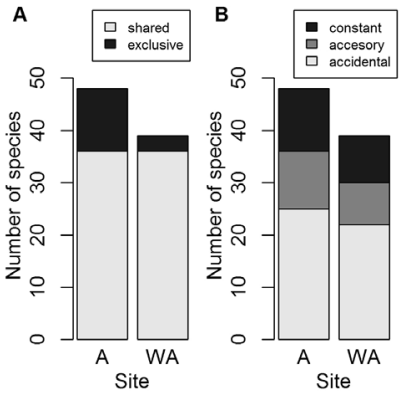

Figure 2. Richness of fishes at two sites of São Cristóvão beach, eastern equatorial coast of Brazil, one with drift algae (A) and another devoid of vegetation (WA). A: number of species at each site, showing the large contribution of shared species to total richness; B: number of species by occurrence class at each site.

Table 2. Ecological descriptors of fish assemblages from two sites on São Cristóvão beach, eastern equatorial coast of Brazil. One site with drift algae (A) and another with bare substrate (WA). All values expressed as mean \pm standard deviation.

\begin{tabular}{lcc}
\hline & Site A & Site WA \\
\hline Species richness & $15.25 \pm 5.45$ & $14.08 \pm 2.75$ \\
Abundance & $250.92 \pm 173.92$ & $171.25 \pm 155.42$ \\
Shannon's diversity (H) & $1.58 \pm 0.66$ & $1.86 \pm 0.40$ \\
Pielou's eveness (J) & $0.57 \pm 0.19$ & $0.71 \pm 0.13$ \\
\hline
\end{tabular}
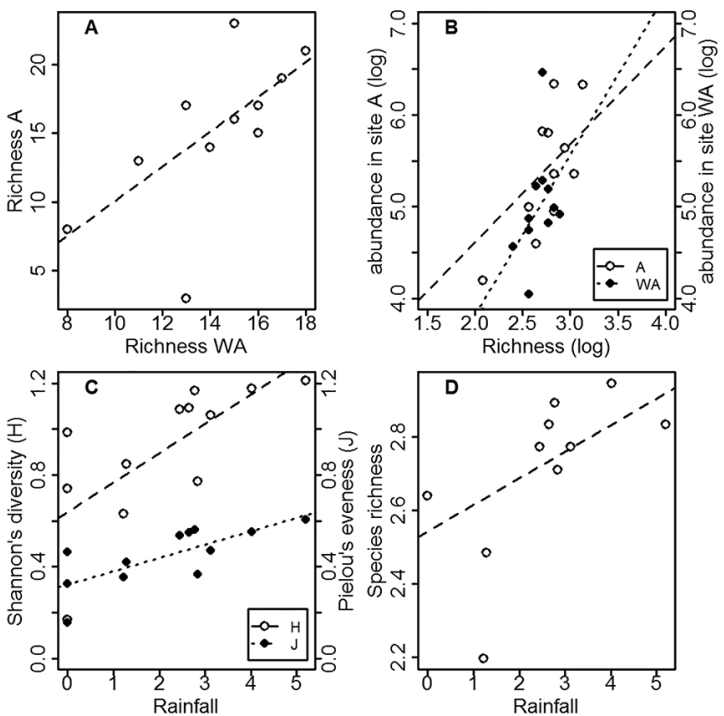

Figure 3. Significant relationships observed between climatic variables and fish community descriptors at two sites of São Cristóvão beach, eastern equatorial coast of Brazil, one with drift algae (A) and another devoid of vegetation (WA). A: positive relationship between richness at both sites; B: positive relationship between species richness and individual abundances at both sites; C: positive relationships between rainfall, Shannon's index of diversity and Pielou's index of eveness at site $\mathrm{A}$; and $\mathrm{D}$ positive relationship between rainfall and species richness at site WA.

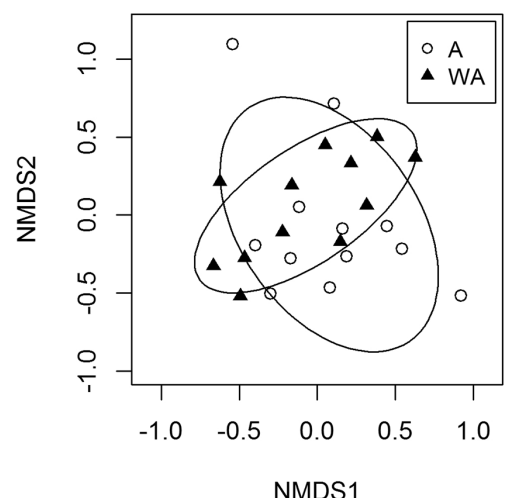

Figure 4. Non-metric multidimensional scaling (nMDS) of fish assemblages from one site with drift algae (A) and one site devoid of vegetation (WA) of São Cristóvão beach, eastern equatorial coast of Brazil. Constructed with data from the whole year. Stress $=0.20$.

tendency was very regular, with the exception of October, when there was a marked fall in Bray-Curtis dissimilarity (Figure 5A).

The tendency of temporal variation in the similarity of assemblages was also suggested by the negative correlation between Bray-Curtis and rainfall $(\mathrm{r}=-0.68$, $p=0.01$, Figure $5 \mathrm{~B}$ ), which indicates that in less rainy months (typically those of the second half of the year) the differences between the communities were greater. If we consider only these dry months, with the exception of October, the nMDS resulted in a good representation of the data (stress $=0.13$ ) and the ANOSIM was significant $(\mathrm{r}=0.268, p=0.015)$, evidencing the differences between assemblages in the dry season (Figure 6).

SIMPER analysis showed that the species which contributed most to the differences between assemblages in the dry season were: Cathorops spixii, Pomadasys corvinaeformis and Larimus breviceps (which contributed with $41.1 \%, 14.7 \%$ and $12.9 \%$ of the variance, respectively).

\section{DISCUSSION}

The presence of drift algae has a strong influence on the structure of fish communities on tropical sandy beaches (ANDRADES et al., 2004). Seaweed build-ups usually favor increased abundances of fish species (KULCZICK et al., 1981). However, contrary to our first hypothesis, no such pattern was observed in the present study. Furthermore, we had expected that environmental complexity would influence the diversity of fish 

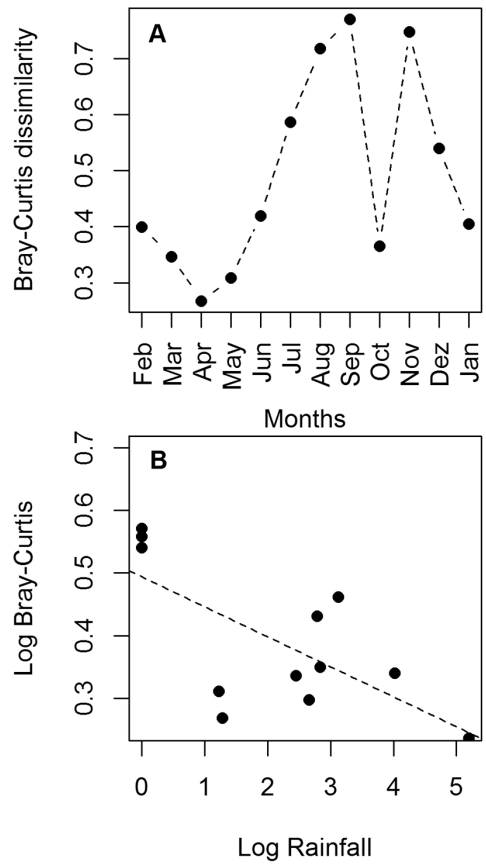

Figure 5. Variations in Bray-Curtis dissimilarity between fish assemblages from a site with drift alga and a site devoid of vegetation, both at São Cristóvão beach, eastern equatorial coast of Brazil. A: changes over the months; B: negative relationship between Bray-Curtis dissimilarity and rainfall, suggesting that fish communities became more similar during the rainy season.

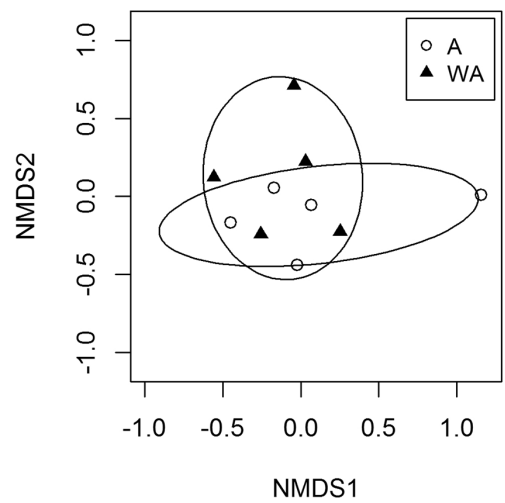

Figure 6. Non-metric multidimensional scaling (nMDS) of fish assemblages from one site with drift algae (A) and one site devoid of vegetation (WA) of São Cristóvão beach, eastern equatorial coast of Brazil. Only dry season data were included. Stress $=0.13$.

assemblages in sites with drift algae, but this was not observed either. This lack of differences may be due to the proximity of the two locations, which should share the same regional pool of species, as well as the exchange of individuals.

The commonest families were the same in both locations, with Scianidae and Ariidae being the most species-rich. Both families are composed of generalist species that typically inhabit sandy-muddy soft-bottoms (MENEZES; FIGUEIREDO, 1980; LE BAIL et al., 2000). This suggests that, besides the presence of drift algae, both sites shared the same environmental conditions, particularly regarding the nature of the substrate.

Over the months, only one individual of a herbivorous species (Acanthurus chirurgus) was found, suggesting that drift algae is not a direct source of food for the fish assemblages. This is in agreement with the observations of other studies which have shown that drift algae accumulations are dominated by omnivorous and detritivorous species (GORE et al., 1981; KIRKMAN; KENDRICK, 1997). The similarity of feeding habits and trophic levels of fish assemblages in sites A and WA also points to the similarity of environmental conditions and species composition of both locations.

Despite the similarities between sites, our data suggest that at least some key ecological features were different as between the two both locations. The presence of drift seaweeds suggests that hydrodynamics is less intense in site A than in WA. Being passively transported, drifting algae are directly related to local hydrodynamics (BELL; HALL, 1997), tending to accumulate in low energy regions (BIBER, 2007a). The intermediate disturbance hypothesis states that, in stable environments, abiotic disturbances are not capable of removing species at a sufficient rate to prevent competitive exclusion, which often results in increased dominances by stronger competitors (DIAL; ROUGHGARDEN, 1998; ROXBURGH et al., 2004). Such a pattern may explain the differences observed in species evenness, which was significantly higher in the more hydrodynamic site WA.

Furthermore, the influence of rainfall was different in the two sites. In WA, richness diminished during the dry season, whereas in A the number of species remained stable throughout the year. On the other hand, in the absence of rain, evenness diminished in $\mathrm{A}$, lowering the site's diversity. This suggests an increased dominance, and a more intense competition in the dry season in this particular station. These differences were strong enough to cause a marked differentiation between the two locations in the dry season. Despite the lack of specific data for the study sites, this differentiation may have been caused by a complex interplay between drifting algae and primary productivity, the latter of which usually increases during rainy seasons in shallow marine 
environments along the Brazilian coast (BARROS et al., 2013; BARROS; ROCHA-BARREIRA, 2013; BARROS; ROCHA-BARREIRA, 2014; CAVALCANTE et al., 2014).

In the present study, the species Cathorops spixii, Pomadasys corvinaeformis and Larimus breviceps were the most influential in the discrimination between $\mathrm{A}$ and WA, notedly in the dry season. These species are predators of vagile invertebrates (MENEZES; FIGUEREDO, 1985; CARVALHO-FILHO, 1999), which are a common food item in sandy-muddy substrates, particularly when associated with drifting alga masses (HOLMQUIST, 1994; BIBER, 2007b). These fishes also form shoals (MENEZES; FIGUEREDO, 1985; CARVALHO-FILHO, 1999) and may have influenced dominance relationships, which were significantly higher in site A.

The present study presents evidence that fish assemblages in habitats with and without drifting seaweeds are not static and may become similar, depending on the environmental conditions. Our results suggest that there is a complex relationship between primary productivity, trophic level and the structure of fish assemblages. Such relationships indicate that efficient management measures depend on the knowledge of how fish assemblages interact with their environments on large spatio-temporal scales.

\section{REFERENCES}

ANDRADES, R.; GOMES, M. P.; PEREIRA-FILHO, G. H.; SOUZA-FILHO, J. F.; ALBUQUERQUE, C. Q.; MARTINS, A. S. The influence of allochthonous macroalgae on the fish communities of tropical sandy beaches. Estuar. Coast. Shelf Sci., v. 144, p. 75-81, 2014.

BARREIROS, J. P.; FIGNA, V.; HOSTIM-SILVA, M.; SANTOS, R. S. Seasonal Changes in a Sandy Beach Fish Assemblage at Canto Grande, Santa Catarina, South Brazil. J. Coast. Res., v. 20, n. 3, p. 862-870, 2004.

BARROS, K. V. S.; ROCHA-BARREIRA, C. A. Influence of environmental factors on a Halodule wrightii Ascherson meadow in northeastern Brazil. Braz. J. Aquat. Sci. Technol., v. 18, n. 2, p. 31-41, 2014.

BARROS, K. V. S.; ROCHA-BARREIRA, C. A. Responses of the molluscan fauna to environmental variations in a Halodule wrightii Ascherson ecosystem from Northeastern Brazil. An. Braz. Acad. Ciênc., v. 85, n. 4, p. 1397-1410, 2013.

BARROS, K. V. S.; XIMENES, C. F.; CARNEIRO, P. B. M.; ROCHA-BARREIRA, C. A.; MAGALHÃES, K. M. Influence of the shoot density of Halodule wrightii Ascherson from rocky and sandy habitats on associated macroalgal communities. Braz. J. Oceanogr., v. 61, n. 4, p. 205-214, 2013.

BELL, S. S., HALL, M. O. Drift macroalgal abundance in seagrass beds: investigating large-scale associations with physical and biotic attributes. Mar. Ecol. Prog. Ser., v. 147, p. 277-283, 1997.
BIBER, P. D. Transport and persistence of drifting macroalgae (Rhodophyta) are strongly influenced by flow velocity and substratum complexity in tropical seagrass habitats. Mar. Ecol. Prog. Ser., v. 343, p. 115-122, 2007a.

BIBER, P. D. Hydrodynamic transport of drifting macroalgae through a tidal cut. Estuar. Coast. Shelf Sci., v. 74, n. 3, p. 565$569,2007 b$.

BRAY, R. J.; CURTIS, J. T. An ordination of the upland forest communities of southern Wisconsin. Ecol. Monogr., v. 27, n. 4, p. 325-349, 1957.

CARVALHO-FILHO, A. Peixes: costa Brasileira. 3.ed. São Paulo: Melro, 1999. 320 p.

CAVAlCANTE, L. L.; AMORIM, L. A.; COSTA, F. N.; ROCHA-BARREIRA, C. A.; BARROS, K. V. S. Variações no prado de Halodule wrightii Ascherson e macrofauna associada na praia da Pedra Rachada, Paracuru, Ceará, Brasil. Rev. Educ. Cient. Cult., v. 1, n. 2, p. 1-9, 2014.

DAJOZ, R. Ecologia geral. 4.ed. Petrópolis: Vozes, 1983. 472 p.

DIAL, R.; ROUGHGARDEN, J. Theory of marine communities: the intermediate disturbance hypothesis. Ecology, v. 79, n. 4, p. 1412-1424, 1998.

EVERETT, R. A. Macroalgae in marine soft-sediments communities: effects on benthic faunal assemblages. J. Exp. Mar. Biol. Ecol., v. 175, n. 2, p. 253-274, 1994.

FOWLER, A. M.; BOOTH, D. J. Seasonal dynamics of fish assemblages on breakwaters and natural rocky reefs in a temperate estuary: consistent assemblage differences driven by sub-adults. Plos ONE, v. 8, n. 9, p. e75790, 2013.

GALVÁN-PIÑA, V. H.; GALVÁN-MAGAÑA, F.; ABITIACÁRDENAS, L. A.; GUTIÉRREZ-SÁNCHEZ, F. J.; RODRIGUEZ-ROMERO, J. Seasonal structure of fish assemblages in rocky and sandy habitats in Bahía de la Paz, Mexico. Bull. Mar. Sci., v. 72, n. 1, p. 19-35, 2003.

GORE, R. H.; GALLAHER, E. E.; SCOTTO, L. E.; WILSON, K. A. Studies on decapod crustacea from theIndian River Region of Florida: XI. Community composition, structure, biomass andspecies-areal relationships of seagrass and drift algaeassociated macrocrustaceans. Estuar. Coast. Shelf. Sci., v. 12, n. 4, p. 485-508, 1981.

HOLMQUIST, J. G. Benthic microalgae as a dispersal mechanism for fauna: influence of a marine tumbleweed. J. Exp. Mar. Biol. Ecol., v. 180, n. 2, p. 235-251, 1994.

IDEMA - Instituto de Desenvolvimento Sustentável e Meio Ambiente do Rio Grande do Norte. Secretaria de estado do meio ambiente e dos recursos Hídricos - Semarh. Perfil do seu município, Areia Branca. Natal, 2008.

KINGSFORD, M. J. Linear oceanographic features: A focus for research on recruitment processes. Austral Ecol., v. 15, n. 4, p. 391-401, 1990.

KINGSFORD, M. J. Drift algae and small fish in coastal waters of northeastern New Zealand. Mar. Ecol. Prog. Ser., v. 80, 41-55, 1992.

KINGSFORD, M. J. Drift algae: a contribution to near-shore habitat complexity in the pelagic environment and an attractant for fish. Mar. Ecol. Prog. Ser., v. 116, p. 297-301, 1995.

KIRKMAN, H.; KENDRICK, G. A.; Ecological significance and commercial harvesting of drifting and beach-cast macroalgae and seagrasses in Australia: a review. J. Appl. Phycol., v. 9, n. 4, p. 311-326, 1997. 
KULCZYCKI, G. R.; VIRNSTEIN, R. W.; NELSON, W. G. The relationship between fish abundance and algal biomass in a seagrass-drift algae community. Estuar. Coast. Shelf Sci., v. 12, n. 3, p. 341-347, 1981.

LE BAIL, P. Y.; KEITH, P.; PLANQUETTE, P. Atlas des poissons d'eau douce de Guyane. (tome 2, fascicule II). Paris: Publications scientifiques du Muséum national d'Histoire naturelle, 2000. 307 p.

MASUDA, R. Seasonal and interannual variation of subtidal fish assemblages in Wakasa Bay with reference to the warming trend in the Sea of Japan. Environ. Biol. Fishes, v. 82, n. 4, p. 387-399, 2008.

MENEZES, N. A.; FIGUEIREDO, J. L. Manual de Peixes marinhos do sudeste do Brasil: IV Teleostei (3). São Paulo: Museu de Zoologia da Universidade de São Paulo, 1980. 96 p.

MENEZES, N. A.; FIGUEIREDO, J. L. Manual de Peixes marinhos do sudeste do Brasil: V Teleostei (4). São Paulo: Museu de Zoologia da Universidade de São Paulo, 1985. 105 p.

NORTON, T. A.; MATHIESON, A. C. The biology of unattached seaweeds. Prog. Phycol. Res., v. 2, p. 333-386, 1983.

ÓLAFSSON, E.; INGÓLFSSON, A.; STEINARSDÓTTIR, M. B. Harpacticoid copepod communities of floating seaweed: controlling factors and implications for dispersal. Hydrobiologia, v. 453/454, n. 1, p. 189-200, 2001. http:// dx.doi.org/10.1590/S1679-87592016124006404
RIBEIRO, J.; BENTES, L.; COELHO, R.; GONÇALVES, J. M. S.; LINO, P. G.; MONTEIRO, P.; ERZINI, K. Seasonal, tidal and diurnal changes in fish assemblages in the Ria Formosa lagoon (Portugal). Estuar. Coast. Shelf Sci., v. 67, n. 3, p. 461-474, 2006.

RIEGL, B. M.; MOYER, R. P.; MORRIS, L. J.; VIRNSTEIN, R.W.; PURKIS, S. J. Distribution and seasonal biomass of drift macroalgae in the Indian River Lagoon (Florida, USA) estimated with acoustic seafloor classification. J. Exp. Mar. Biol. Ecol., v. 326, p. 89-104, 2005.

ROXBURGH, S. H.; SEHA, K.; WILSON, J. B. The intermediate disturbance hypothesis: patch dynamics and mechanisms of species coexistence. Ecology, v. 85, n. 2, p. 359-371, 2004.

SMITH, K. N; HERRNLUND, W. F. Predation on early juvenile spiny lobsters Panulirus argus (Latreille): influence of size and shelter. J. Exp. Mar. Biol. Ecol., v. 157, n. 1, p. 3-18, 1992.

STONER, A. W.; LIVINGSTON, R. J. Distributional ecology and food habits of the banded blenny, Paraclinus fasciatus (Clinidae): a resident in a mobile habitat. Mar. Biol., v. 56, n. 3, p. 239-246, 1980.

VIRNSTEIN, R. W.; HOWARD, R. K. Motile epifauna of marine macrophytes in the Indian River Lagoon, Florida. I. Comparisons among three species of seagrasses from adjacent beds. Bull. Mar. Sci., v. 41, n. 1, p. 1-12, 1987.

WANG, J. D.; LUO, J.; AULT, J. S. Flows, salinity and some implications on larval transport in South Biscayne Bay, Florida. Bull. Mar. Sci., v. 72, n. 3, p. 695-723, 2003. 
